\title{
PENGARUH MODEL PEMBELAJARAN TRADE A PROBLEM DENGAN PEMBERIAN REWARD TERHADAP KEMAMPUAN KOMUNIKASI MATEMATIS SISWA KELAS VII SMP N.1 GUNUNG MALELA
}

\author{
Christa Voni Roulina Sinaga \\ Prodi Pendidikan Matematika FKIP UHN Pematangsiantar \\ christaunimed@gmail.com
}

\begin{abstract}
The purpose of this study was to determine the effect of the trade a problem learning model by rewarding students' mathematical communication skills. This type of research is quasi-experimental research by determining one class of research samples taken randomly as the experimental class. In this study the method of data retrieval is carried out by applying to an experimental class a treatment condition. The population in this study were all VII grade students of SMP N 1 Gunung Malelala. The results show a strong relationship between the Trade A Problem learning model and reward for students' communication skills. Based on the results of the calculation of the regression equation the equation $\hat{Y}=27,87+0,64 X$ is obtained. In this equation the regression direction coefficient $(b)=0.64$ is positive, which means that the two variables have a positive linear relationship.
\end{abstract}

Keywords: trade a problem, mathematical communication skills.

\begin{abstract}
Abstrak. Tujuan penelitian ini adalah untuk mengetahui pengaruh model pembelajaran trade a problem dengan pemberian reward terhadap kemampuan komunikasi matematis siswa. Jenis penelitian ini adalah eksperimen semu (quasi-experimental research) dengan menentukan satu kelas sampel penelitian yang diambil secara acak (random) sebagai kelas eksperimen. Dalam penelitian ini cara pengambilan data yang dilakukan yaitu dengan mengenakan kepada satu kelas eksperimen suatu kondisi perlakuan (treatment). Yang menjadi populasi dalam penelitian ini adalah seluruh siswa kelas VII SMP N 1 Gunung Malelala. Hasil menunjukkan adanya hubungan yang kuat antara model pembelajaran Trade A Problem dengan Reward terhadap kemampuan komunikasi siswa. Berdasarkan hasil perhitungan persamaan regresi diperoleh persamaan $\hat{Y}=27,87+0,64 X$. Pada persamaan tersebut koefisien arah regresi $(b)=0,64$ bertanda positif, yang artinya bahwa kedua variabel mempunyai hubungan yang linear positif.
\end{abstract}

Kata Kunci: trade a problem, kemampuan komunikasi matematis.

\section{PENDAHULUAN}

Pendidikan merupakan usaha agar manusia dapat mengembangkan potensi dirinya melalui proses pembelajaran. Pendidikan mempunyai pengaruh besar terhadap kemajuan teknologi suatu bangsa. Kemapanan dalam bidang pendidikan akan mendorong teknologi kearah yang lebih baik. Hampir semua Negara maju memiliki tingkat pendidikan yang lebih baik dibandingkan Negara berkembang. Hal ini merupakan bukti pentingnya pendidikan dalam mendukung kemajuan teknologi.

Perubahan paradigma dalam dunia pendidikan menuntut adanya perubahan pada tujuan pendidikan yang akan dicapai. Perubahan dalam tujuan pendidikan selanjutnya diimplementasikan terhadap kurikulum yang berlaku. Sanjaya (2011) menyatakan bahwa: "Dalam konsep kurikulum sebagai mata pelajaran biasanya erat kaitannya dengan usaha untuk memperoleh ijazah. Ijazah sendiri pada dasarnya menggambarkan kemampuan. Artinya, apabila siswa telah berhasil mendapatkan ijazah berarti dia telah menguasai pelajaran sesuai kurikulum yang berlaku. Kemampuan tersebut tercermin dalam nilai setiap mata pelajaran yang terkandung dalam ijazah itu. Siswa yang belum memiliki kemampuan atau belum memperoleh nilai berdasarkan standar tertentu tidak akan mendapat ijazah, walaupun mungkin saja mereka telah mempelajari kurikulum tersebut”. 
Implementasi kurikulum tahun 2013, melalui para guru yang mengarahkan siswa untuk mengusung paradigma belajar abad 21, diharapkan dapat membantu siswa untuk melakukan observasi, bertanya, bernalar, dan mengkomunikasikan apa yang diperoleh atau diketahuinya yang merupakan tujuan pendidikan nasional, yakni jabaran UUD 1945 tentang pendidikan dituangkan dalam Undang-undang No. 20 Tahun 2003 pasal 3 menyebutkan bahwa: "Pendidikan nasional berfungsi mengembangkan kemampuan dan membentuk watak serta peradaban bangsa yang bermartabat dalam rangka mencerdaskan kehidupan bangsa, bertujuan untuk berkembangnya potensi peserta didik agar menjadi manusia yang beriman dan bertakwa kepada Tuhan yang maha esa, berakhlak mulia, sehat, berilmu, cakap, kreatif, mandiri dan menjadi warga negara yang demokratis serta bertanggung jawab".

Selain itu siswa diharapkan memiliki kompetensi sikap, keterampilan, dan pengetahuan yang lebih baik, yang pada akhirnya akan mewujudkan terciptanya masyarakat belajar (learning society), dimana setiap anggota masyarakat berhak mendapatkan pendidikan (education for all) dan menjadi pembelajaran seumur hidup (longlife education). Hasbullah (2011) menyebutkan bahwa: "Setiap warga Negara mempunyai hak yang sama untuk memperoleh pendidikan yang bermutu, setiap warga negara berhak mendapatkan kesempatan meningkatkan pendidikan sepanjang hayat".

Salah satu indikator yang menunjukkan mutu pendidikan matematika di Indonesia cenderung rendah adalah hasil penilaian Internasional mengenai prestasi belajar siswa khususnya matematika. Badan Penelitian dan Pengembangan (Litbangkemdikbud, 2011) melaporkan hasil survey Trends in Internasional Mathematics and Science Study (TIMSS) dan Programme for Internasional Students Assesment (PISA) sebagai berikut: "Pada tahun 2003 menunjukkan prestasi belajar siswa SMP Indonesia berada di peringkat 34 dari 45 negara. Walaupun rerata skor naik 411 dibanding 403 pada tahun 1999, Indonesia masih berada dibawah rerata untuk wilayah ASEAN. Prestasi belajar siswa Indonesia pada TIMSS 2007 lebih memprihatinkan lagi, karena skor siswa turun menjadi 397, jauh lebih rendah dibandingkan rerata skor Internasional yaitu 500. Prestasi siswa pada TIMSS 2007 berada pada peringkat 36 dari 49 negara. Bahkan hasil lebih buruk ditunjukkan dari hasil penelitian terbaru pada TIMSS 2011 yakni peringkat 39 dari 43 negara.

Pada PISA 2003, Indonesia berada di peringkat 38 dari 40 negara, dengan rerata skor 360. Pada tahun 2006 rerata skor naik menjadi 391, yaitu peringkat 50 dari 57 negara. Sedangkan pada tahun 2013, Indonesia hanya menempati peringkat 61 dari 65 negara dengan rerata skor 371, sementara rerata skor Internasional adalah 496, pada tahun 2017 Indonesia menempati peringkat 64 dari 65 negara dengan rerata skor 375. Hasil TIMMS dan PISA yang rendah terhadap prestasi belajar anak Indonesia tentunya disebabkan oleh banyak faktor".

Salah satu pokok bahasan yang diajarkan di SMP kelas VII adalah Persamaan dan pertidaksamaan linier dua variabel. Penggunaan materi ini banyak ditemukan dalam kehidupan sehari-hari serta banyak digunakan dalam disiplin ilmu lain. Materi Persamaan dan pertidaksamaan linier satu variabel selain diberikan di SD, SMP, dan SMA juga diberikan diperguruan tinggi. Hal ini berarti konsep-konsep, prinsip dan aturan-aturan dalam Persamaan dan pertidaksamaan linier satu variabel harus benar-benar dipahami dan dikuasai oleh siswa secara mendalam. Dari hasil survey peneliti ke beberapa sekolah dengan melihat daftar kumpulan nilai (hasil rapor bulanan) yang terkait dengan materi Persamaan dan pertidaksamaan linier satu variabel, diperoleh hasil yang cukup memprihatinkan, serta peneliti juga mewawancarai guru matematika disekolah-sekolah sedikit kewalahan dalam menyampaikan materi Persamaan dan pertidaksamaan linier satu variabel. 
Tabel 1. Rata-rata hasil perolehan nilai rapor bulanan siswa kelas VII SMP Gunung Malela

\begin{tabular}{clc}
\hline No & \multicolumn{1}{c}{ Nama Sekolah } & Rata-rata nilai \\
\hline 1 & SMP Negeri 1 Gunung Malela & 60,30 \\
\hline 2 & SMP Negeri 2 Gunung Malela & 60,60 \\
\hline 3 & SMP Swasta Taman Siswa & 55,00 \\
\hline 4 & SMP Swasta Gotong Royong & 56,50 \\
\hline \multicolumn{2}{l}{ Sumber: DKN Siswa Kelas VII SMP Gunung Malela pada Mata Pelajaran Matematika }
\end{tabular}

Djamarah (2010) menyatakan bahwa: "Proses belajar mengajar adalah suatu aspek dari lingkungan sekolah yang diorganisasi. Lingkungan ini diatur serta diawasi agar kegiatan belajar mengajar terarah sesuai tujuan pendidikan". Selanjutnya Portal Dunia Guru menyatakan bahwa : "Terdapat fenomena yang dapat dilihat bagaimana tindakan guru dikelas agar hasil Kegiatan Belajar Mengajar (KBM) tercapai dengan optimal". Namun kenyataan banyak guru matematika tidak mampu melaksanakan KBM dengan baik, walaupun seluruh guru telah dibekali kompetensi guru. Fenomena tersebut antara lain adalah: 1) Banyak siswa malas belajar matematika hanya karena cara guru yang mengajar tidak sesuai dengan keinginan siswa; 2) Siswa selalu merasa bosan dalam belajar matematika dan akibatnya hasil belajar matematika tidak sesuai harapan; 3) Ada sebagian siswa berpendapat bahwa guru matematika dalam penyampaian materi tidak dapat menyampaikannya dengan menarik dan menyenangkan; dan 4) Guru matematika yang mengajar terlalu monoton bahkan cenderung kurang dapat berkomunikasi dengan siswa sehingga suasana kelas menjadi kaku.

Ternyata bukan materi pelajaran matematika sukar dicerna tetapi beberapa hal yang dipaparkan diatas telah menjadi momok yang menyulitkan siswa dalam belajar matematika. Pembelajaran matematika di beberapa sekolah di Indonesia sejauh ini masih didominasi pembelajaran konvensional dengan paradigma guru mengajar hanya berorientasi pada hasil belajar yang dapat diamati dan diukur. Siswa pasif dan guru cenderung memindahkan informasi yang sebanyak-banyaknya kepada siswa sehingga konsep, prinsip dan aturan-aturan sulit dipahami oleh siswa, tidak dapat menerapkan konsep dan sukar untuk mengadaptasikan pengetahuannya terhadap lingkungan belajarnya dan menjadikan matematika tidak bermakna bagi siswa. Walaupun banyak siswa mampu menghafal materi yang diterimanya tetapi sering kali tidak memahami secara mendalam substansi materinya. Sebagian besar siswa tidak mampu menghubungkan antara yang mereka pelajari dengan bagaimana pengetahuan tersebut akan dimanfaatkan. Hal ini juga mengakibatkan prestasi belajar matematika Indonesia sangat rendah.

Usman (2010) mengatakan bahwa aktivitas belajar murid adalah aktivitas jasmaniah maupun aktivitas mental, aktivitas belajar murid memiliki kadar atau bobot yang berbeda bergantung pada segi tujuan yang mana yang akan dicapai dalam kegiatan belajar mengajar. Tujuan ini dapat dicapai dengan aktivitas dan pola pikir matematika yang dapat memfasilitasi siswa untuk belajar menemukan kembali rumus ataupun teori matematika oleh sipembelajar itu sendiri dibawah bimbingan guru (guided re-invention) sebagaimana para matematikawan menemukan rumus teori tersebut. Hal ini tidak mungkin bisa dicapai hanya melalui hafalan, latihan pengerjaan soal bersifat rutin, atau dengan proses pembelajaran konvensional.

NCTM (1989) merekomendasikan ada 5 kompetensi standar matematika (Doing math) yang utama yaitu: "kemampuan Pemecahan Masalah (Problem Solving), Komunikasi (Communication), Koneksi (Connection), Penalaran (Reasoning), Representase (Representation)". Salah satu dari lima standar proses prinsip-prinsip dan standar dari NCTM, yaitu komunikasi (Van de Walle, 2007) Komunikasi biasa membantu pembelajaran siswa tentang konsep matematika baru ketika mereka memerankan situasi, 


\section{Christa Voni Roulina Sinaga \\ Pengaruh Model Pembelajaran Trade A Problem dengan Pemberian Reward...}

menggambarkan, menggunakan objek, memberikan laporan dan penjelasan verbal. Juga ketika menggunakan diagram, menulis dan menggunakan simbol matematika. Kesalahpahaman biasa diidentifikasi dan ditunjukkan. Keuntungan sampingannya adalah bisa mengingatkan siswa bahwa mereka berbagi bertanggung jawab dengan guru atas pembelajaran yang muncul dalam pelajaran itu.

Dari prinsip-prinsip dan standar NCTM yang dikemukakan di atas, maka dapat dikatakan bahwa kemampuan komunikasi matematika merupakan hal yang sangat penting dan perlu ditingkatkan dalam pembelajaran matematika, untuk meningkatkan hasil belajar matematika. Aspek komunikasi melatih siswa untuk dapat mengkomunikasikan gagasannya, baik komunikasi lisan maupun komunikasi tulisan". Tiga aspek komunikasi yang diperlukan dalam komunikasi matematika, yakni keakuratan informasi, dalam komunikasi matematika keakuratan juga sangat diperlukan agar informasi yang disampaikan tidak keliru. Bagian ke dua yang tidak kalah pentingnya dalam komunikasi adalah menyampaikan komunikasi dengan lengkap, dikatakan lengkap apabila informasi tentang ide/pengetahuan matematika dalam menyelesaikan masalah matematika disampaikan secara utuh. Selain keakuratan dan kelengkapan dalam komunikasi matematika, aspek kelancaran juga merupakan salah satu hal yang diperlukan. Dengan banyaknya gagasan/ide yang dimiliki oleh seorang siswa dalam menyelesaikan masalah matematika diharapkan siswa tersebut tidak macet ketika mengkomunikasikan pemahaman matematikanya.

Komunikasi dalam matematika menolong guru memahami kemampuan siswa dalam menginterprestasikan dan mengekspresikan pemahamannya tentang konsep dan proses matematika yang mereka pelajari. Namun, pada kenyataannya setelah dilakukan observasi di SMP Negeri 1 Gunung Malela menunjukkan bahwa kemampuan komunikasi siswa masih rendah terlihat dari soal yang diberikan pada siswa yaitu: Seorang petani mempunyai sebidang tanah berbentuk persegi panjang. Lebar tanah tersebut $6 \mathrm{~m}$ lebih pendek daripada panjangnya. Jika keliling tanah $60 \mathrm{~m}$, a) buatlah model matematika dari keterangan diatas. b) tentukan luas tanah petani tersebut.

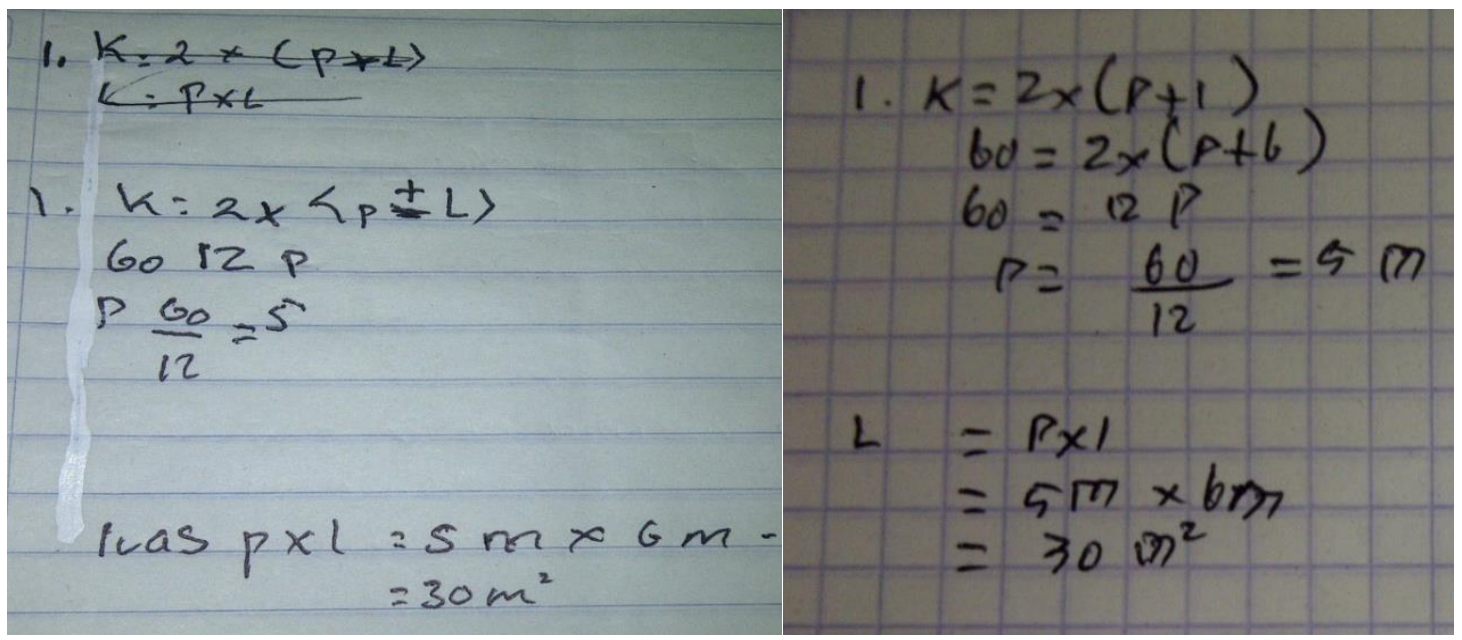

Gambar 1. Jawaban kemampuan komunikasi matematis siswa

Dari hasil analisis lembaran jawaban siswa di atas bahwa dari 35 siswa banyak siswa yang mengalami kesulitan dalam menjawab soal tersebut antaranya 5 siswa tidak mengetahui apa yang diketahui, 20 siswa sulit mengemukakan ide matematikanya secara tulisan, ditemukan kesalahan siswa dalam menafsirkan soal, menuliskan simbol dan menjawab dengan bahasa matematika serta jawaban yang disampaikan oleh siswa sering kurang terstruktur sehingga sulit dipahami oleh guru maupun temannya akibatnya 
kemampuan komunikasi matematika siswa rendah karena hasil pre-tes siswa rata-rata 50 atau 2 dengan predikat c .

Berdasarkan Peraturan Pemerintah Nomor 65 tahun 2013 tentang standar proses pembelajaran, maka dapat dikatakan bahwa model pembelajaran yang sesuai dengan sasaran penilaian berbasis proses adalah sekolah yang menerapkan model pembelajaran berbasis konstruktivistik, antara lain model project-based learning, problem-based learning, discovery learning, cooperatif learning, contextual learning. Hal ini didukung oleh pernyataan Nur, bahwa kunci keberhasilan penggunaan asesmen berbasis kelas adalah melibatkan partisipasi Matematikasi siswa dalam proses pembelajaran dengan pendekatan scientific learning (Nur, 2003).

Untuk mencapai tujuan di atas perlu adanya model pembelajaran yang bisa mengatasi masalah pendidikan yang telah diungkapkan di atas, Istarani (2012) menyatakan bahwa: "Model pembelajaran adalah seluruh rangkaian penyajian materi ajar yang meliputi segala aspek sebelum, sedang dan sesudah pembelajaran yang dilakukan guru serta segala fasilitas yang terkait yang digunakan secara langsung atau tidak langsung dalam proses belajar mengajar". Yang dimaksud harus memiliki syarat antara lain dapat membuat siswa mampu mengonstruksi pengetahuan, dapat membuat siswa mandiri dalam belajar, dapat meningkatkan interaksi siswa, dapat melatih siswa untuk mengomunikasikan idenya dan dapat meningkatkan pengetahuan siswa memecahkan masalah. Dengan ciri-ciri yang dimiliki tersebut diharapkan model pembelajaran itu akan berakibat pada meningkatnya hasil belajar siswa.

Rendahnya kemampuan komunikasi matematika siswa tidak terlepas dari kemampuan guru dalam mengajarkan matematika. Selama ini dirasakan bahwa sebagian guru kurang tepat memilih model pembelajaran yang digunakan untuk menyampaikan materi pelajaran matematika. Untuk mengatasi hal-hal tersebut, maka seorang guru harus mampu memilih dan menentukan model pembelajaran yang sesuai dengan materi pelajaran dan kebutuhan belajar siswa. Salah satu solusi nya adalah dengan menerapkan model pembelajatan Trade A Problem dengan Reward. Model pembelajaran Trade A Problem adalah model pebelajaran koopertif yang berisi suatu struktur yang digunakan untuk melatih konsep-konsep yang telah diajarkan yang telah diajarkan guru kepada siswa. Sehingga model pembelajaran Trade A Problem ini merupakan solusi yang tepat untuk mengembangkan kemampuan komunikasi matematika siswa.

\section{METODE}

Jenis penelitian ini adalah eksperimen semu (quasi-experimental research) dengan menentukan satu kelas sampel penelitian yang diambil secara acak (random) sebagai kelas eksperimen. Dalam penelitian ini cara pengambilan data yang dilakukan yaitu dengan mengenakan kepada satu kelas eksperimen suatu kondisi perlakuan (treatment). Yang menjadi populasi dalam penelitian ini adalah seluruh siswa kelas VII SMP N 1 Gunung Malelala. Pengambilan sampel dalam penelitian ini dilakukan secara Simple Random Sampling. Sampel dalam penelitian ini diambil satu kelas.

Rancangan penelitian yang digunakan adalah One-shot case study. Sampel yang telah ditentukan dibagi menjadi satu kelompok, yaitu kelas eksperimen. Perlakuan yang diberikan pada kelas eksperimen adalah penggunaan model Trade A Problem. Peneliti hanya mengadakan treatment satu kali yang diperkirakan sudah mempunyai pengaruh. Kemudian diadakan post-test dan mengambil kesimpulan.

Tabel 2. Tabel One-Shot Case Study

\begin{tabular}{llll}
\hline Kelompok & Pre-Test & Treatment & Post-Test \\
\hline Eksperimen & - & $\mathrm{X}$ & $\mathrm{O}$ \\
\hline
\end{tabular}


Pengaruh Model Pembelajaran Trade A Problem dengan Pemberian Reward...

\section{HASIL DAN PEMBAHASAN}

Berdasarkan perhitungan data diperoleh $\mathrm{L}_{\text {hitung }}=0,117$ sedangkan $\mathrm{L}_{\text {tabel }}$ dengan $\alpha=$ 0,05 adalah 0,161 . Karena $\mathrm{L}_{\text {hitung }}<\mathrm{L}_{\text {tabel }}$ atau $0,117<0,161$ artinya data berasal dari populasi yang berdistribusi normal. Untuk mengetahui apakah kedua variabel mempunyai hubungan yang linear digunakan persamaan regresi linear:

$$
\widehat{Y}=a+b X
$$

Dari perhitungan diperoleh $a$ sebesar 27,87 dan $b$ sebesar 0,64 sehingga didapat persamaan regresi linearnya:

$$
\widehat{Y}=27,87+0,64 X
$$

Dari hasil perhitungan diperoleh $b$ bernilai positif sebesar 0,64 artinya setiap kenaikan model pembelajaran Trade A Problem dengan Reward sebesar 1 satuan akan meningkatkan kemampuan komunikasi siswa sebesar 0,64 satuan.

Ringkasan perhitungan dari persamaan regresi model pembelajaran Trade A Problem terhadap kemampuan komunikasi siswa. Seperti pada Tabel 3 berikut:

Tabel 3. Analisis Varians untuk Linearitas Regresi

\begin{tabular}{cccccc}
\hline Sumber varians & DK & JK & RJK & $\mathbf{F}_{\text {hitung }}$ & $\mathbf{F}_{\text {tabel }}$ \\
\hline Total & 30 & 169225 & 169225 & & \\
\hline Regresi (a) & 1 & 167253,33 & 167253,33 & 38,57 & 4,20 \\
Regresi (b/a) & 1 & 1142,18 & 1142,18 & & \\
Residu & $30-2$ & 829,49 & 29,62 & & \\
\hline Tuna cocok & $9-2$ & 680,73 & 680,73 & 1,40 & 2,41 \\
kekeliruan & $30-9$ & 148,76 & 68,98 & & \\
\hline
\end{tabular}

Dari tabel di atas dapat diambil kesimpulan yaitu: Jika $F_{\text {hitung }}$ (regresi) lebih besar dari harga $F_{\text {tabel }}$ pada taraf signifikansi 5\% $(\alpha=0,05)$, maka harga $F_{\text {hitung }}$ (regresi) signifikan, yang berarti bahwa koefisien regresi adalah berarti (bermakna). Dalam hal ini, $F_{\text {hitung }}$ (regresi) $=38,57$, sedangkan $\mathrm{F}_{\text {tabel }}$ untuk dk 1:28 (pembilang $=1$; dan penyebut $=28$ untuk taraf signifikan $5 \%=4,20)$. Ini berarti, harga $F_{\text {hitung }}>F_{\text {tabel }}$ yaitu 438,57> 4,20, sehingga hipotesis nol ditolak dan hipotesis alternatif diterima sehingga $F_{\text {hitung }}$ adalah signifikan. Dengan demikian terdapat hubungan fungsional yang signifikan dari persamaan regresi

Ringkasan perhitungan dari persamaan regresi kemampuan komunikasi atas Trade $A$ Problem (X), seperti pada Tabel 5 berikut:

\begin{tabular}{|c|c|c|c|c|c|}
\hline Sumber Varians & $\operatorname{dk}(n)$ & Jumlah Kuadrat (JK) & RK dan RT & $F_{\text {hitung }}$ & $F_{\text {tabel }}$ \\
\hline Tuna Cocok & 7 & 680,73 & 43,23 & \multirow{2}{*}{1,40} & \multirow{2}{*}{2,41} \\
\hline Galat & 21 & 148,76 & 52,58 & & \\
\hline
\end{tabular}

Tabel 5. Hasil Analisis Varians (ANAVA) untuk Linearitas Regresi

Dari Tabel 5 dapat diambil kesimpulan yaitu: Jika $\mathrm{F}_{\text {hitung }}$ (tuna cocok) lebih kecil dari harga $F_{\text {tabel }}$ pada taraf signifikan 5\% $(\alpha=0,05)$, maka harga $F_{\text {hitung }}$ (tuna cocok) non signifikan, yang berarti bahwa hipotesis nol diterima dan hipotesis alternatif ditolak, sehingga regresi kemampuan komunikasi siswa (Y) atas model pembelajaran Trade A Problem $(\mathrm{X})$ adalah linear. Dalam hal ini, $\mathrm{F}_{\text {hitung }}\left(\right.$ tuna cocok) $=1,40$, sedangkan $\mathrm{F}_{(1-0,05 \text {; }}$ 14:14) $=2,41$, dengan demikian harga $F_{\text {hitung }}\left(\right.$ tuna cocok) $<F_{\text {tabel }}$ atau 1,40 $<2,41$. Ini berarti, $\mathrm{H}_{0}$ diterima sehingga harga $\mathrm{F}_{\text {hitung }}$ (tuna cocok) adalah non signifikan. Dengan demikian terdapat model regresi linier. 
Dari persamaan regresi, menghitung jumlah kuadrat, uji signifikan regresi dan uji linearitas regresi dapat disimpulkan bahwa ada pengaruh model pembelajaran Trade $A$ Problem dengan Reward terhadap kemampuan komunikasi siswa.

Untuk menentukan besar hubungan (korelasi) antara variabel $\mathrm{X}$ dan $\mathrm{Y}$ digunakan rumus product moment. Dari hasil perhitungan diperoleh $r_{\text {hitung }}=0,76$. Jika dikonsultasikan dengan tabel angka product moment pada taraf signifikan $0,05 \mathrm{dan} \mathrm{dk}=30$ diperoleh $\mathrm{r}_{\text {tabel }}$ $=0,361$. Karena $r_{\text {hitung }}>r_{\text {tabel }}$ atau 0,386 $>0,361$. Ini berarti terdapat hubungan yang kuat antara variabel $\mathrm{X}$ dan variabel $\mathrm{Y}$ atau terdapat hubungan yang kuat antara model pembelajaran Trade A Problem dengan Reward terhadap kemampuan komunikasi siswa. Dengan $\mathrm{r}_{\text {hitung }}=0,76$ diketahui hubungan antara variabel diketahui hubungan antara Trade A Problem dengan Reward terhadap kemampuan komunikasi siswa memiliki pengaruh yang rendah.

Selanjutnya dilakukan uji keberartian koefisien korelasi dengan uji t. Pada Lampiran 27 diperoleh $t_{\text {hitung }}=6,195$ kemudian dikonsultasikan dengan $t_{\text {tabel }} \mathrm{dk}=30$ dan taraf signifikan 0,05 diperoleh $t_{\text {tabel }}=2,048$. Dengan demikian $t_{\text {tabel }}<t_{\text {tabel }}$ atau 6,195<2,214maka perbandingan nilai tersebut menunjukkan adanya hubungan yang berarti. $\mathrm{H}_{0}$ ditolak dan $\mathrm{H}_{1}$ diterima.

Maka untuk mengetahui besarnya pengaruh variabel $\mathrm{X}$ terhadap variabel $\mathrm{Y}$ maka dihitung koefisien determinasi. Pada Lampiran 27, diperoleh hasil perhitungan koefisien determinasi 57,93\%. Kesimpulan akhir adalah bahwa variabel $\mathrm{Y}$ dipengaruhi oleh variabel $\mathrm{X}$ sebesar 57,93\%, sedangkan sisanya dipengaruhi oleh faktor lain atau pengaruh model pembelajaran Trade A Problem dengan Reward terhadap kemampuan komunikasi siswa sebesar 57,93\% sedangkan sisanya dipengaruhi oleh faktor lain.

Setelah diberikan perlakuan terhadap kelas eksperimen yaitu kelas yang diajarkan dengan menggunakan pendekatan preferensi sensori, siswa memiliki antusias yang tinggi untuk belajar karena mereka belajar secara kelompok, berdiskusi dengan teman satu kelompok yang membuat mereka nyaman dan rileks. Dengan menggunakan pendekatan preferensi sensori siswa dilatih menggunakan alat indera yang dimiliki yaitu visual (penglihatan), auditori (pendengaran) dan kinestetik (sentuhan). Sehingga siswa lebih cepat dalam memahami materi pembelajaran yang disampaikan oleh guru.

Pada akhir pertemuan setelah semua materi selesai diajarkan, siswa diberikan PostTest untuk mengukur kemampuan komunikasi siswa terhadap materi yang telah diajarkan yaitu sistem persamaan linier dua variabel. Berdasarkan hasil Post-Test diperoleh rata-rata hasil belajar siswa dengan menggunakan model pembelajaran Trade A Problem dengan Reward adalah 80,93 dengan nilai terendah 64 dan tertinggi 94. Sedangkan unutuk observasi, rata-ratanya adalah 82,46 dengan nilai terendah 71 dan nilai tertinggi 97 . Hal ini menunjukkan bahwa hasil belajar siswa termasuk kategori baik.

\section{KESIMPULAN}

Berdasarkan hasil pengujian regresi didapat koefisien korelasi $(r)=0,76$ termasuk kategori sedang. Hasil menunjukkan adanya hubungan yang kuat antara model pembelajaran Trade A Problem dengan Reward terhadap kemampuan komunikasi siswa. Kemudian dari hasil perhitungan diperoleh koefisien determinasi $\left(\mathrm{r}^{2}\right)=57,93 \%$ artinya pengaruh antara model pembelajaran Trade A Problem dengan Reward terhadap kemampuan komunikasi siswa sebesar 57,93\%, dan selebihnya dipengaruhi oleh variabel atau faktor-faktor lain. Berdasarkan hasil perhitungan persamaan regresi diperoleh persamaan $Y=27,8 \hat{7}+0,64 X$. Pada persamaan tersebut koefisien arah regresi $(b)=0,64$ bertanda positif, yang artinya bahwa kedua variabel mempunyai hubungan yang linear 
Pengaruh Model Pembelajaran Trade A Problem dengan Pemberian Reward...

positif. Kemampuan komunikasi siswa akan meningkat dengan pengaruh model Trade $A$ Problem dengan Reward sebesar 0,64 kali.

\section{DAFTAR PUSTAKA}

Djamarah, Syaiful Bahri. 2010. Guru Dan Anak Didik Dalam Interaksi Edukatif. Jakarta: Rineka Cipta.

Hasbullah. 2011. Dasar-dasar Ilmu Pendidikan. Edisi revisi. Jakarta: Raja Grafindo Persada.

Istarani. 2012. 58 Model Pembelajaran Inovatif. Medan: Media Persada

Litbangkemdikbud. 2011. Survei International TIMSS dan PISA.http://litbangkemdikbud. go.id.

NCTM. 1989. Curriculum and Evaluation Standards for School Mathematics. Reston, VA: NCTM

Nur, M. 2008. Model Pembelajaran Berdasarkan Masalah. Surabaya: PSMS

Trianto. 2011. Mendesain Model Pembelajaran Inovatif-Progresif. Jakarta: Rineka Cipta. Usman, M. U. 2010. Menjadi Guru Profesional. Bandung: Remaja. Rosdakarya.

Van De Walle, J. 2007. Elementary and Middle School Mathematics Sixth Edition. Pearson Education, Inc.

Wina, S. 2011. Kurikulim dan Pembelajaran. Jakarta: Prenada Media Grup. 